\title{
LOCAL EMPLOYMENT DEVELOPMENT AND SUSTAINABLE LABOUR MARKET IN NORTHERN HUNGARY SINCE THE REGIME CHANGE
}

\section{Katalin Lipták ${ }^{*}$, Zoltán Musinszki}

University of Miskolc, Hungary

The peripheral regions of Hungary, such as the Northern Hungarian region and its settlements, are facing a variety of problems and challenges, and in addition to economic difficulties, demographic and labour market challenges also demand increased attention and solutions. Since the change of regime, the region has been facing economic and labour market difficulties. The current labour market faces a combination of labour shortages, automation and robotisation, rapidly changing conditions and high unemployment. In most peripheral regions, the availability of labour resources to meet the needs of the primary labour market is very limited and local labour markets are completely depleted. The unemployed lack skills and experience. The aim of the study is to provide an overview of labour market developments in the Northern Hungarian region since the change of regime and to describe successful local developments. Addressing the situation requires local, municipal-level solutions, which is a real challenge, as there is no single recipe. Local development can and should be built on a toolbox of local development, as solutions based on local resources, local 'heroes', local control and local ideas can be successful. The paper describes such successful local development.

Keywords: labour market, local employment development, Northern Hungarian region

\section{Introduction}

The Northern Hungarian region had a strong industrial base before the regime change, but after 1989 the region's economic situation deteriorated rapidly, which was only moderately recovered. The region's labour market indicators improved after the global economic crisis of 2008, but it is still best described as lagging behind. The development of the Borsod-Abaúj-Zemplén county has determined the weight of the region as a whole, with the county experiencing major discrepancies and hectic trends. In 1930, the number of employed persons in the county was 234,000 , in 1941 it rose from 263,155 to 259,687 , in 1949 to 259,687 , in 1960 to 319,617 and in 1980 to 369,743 (KSH data). Until the early 1980s, the 'industrial region of Borsod' was the most dynamically developing industrial region in Hungary, the 'stronghold' of heavy industry (Simkó, 2008). During this period, a significant population influx took place and mass housing estates were built to provide housing for industrial workers. Forced industrialisation and industrial development through public investment caused a rigid and distorted economic and employment structure (male to female employment ratio) in many respects (Lengyel, 1968).

The period after the 1980s was characterised by a revolution in the dissemination and spread of microelectronics. The spread of information and communication technologies decisively changed the space in which businesses operate, compete and trade, and this development has continued ever since. The information revolution offers firms the opportunity to improve internal efficiency, increase productivity, and bridge the geographical gap between buyers and sellers. The import of technology is a necessary but not sufficient condition for the growth and development of regions. Lack of access to technology makes life difficult for low-income earners and increases poverty levels. Without doubt, technological change is a vital factor for growth and the advancement of developing regions. Many developing regions have experienced a structural transformation of their private economies, which has led to the growth of service industries. New technologies have ensured the strengthening of these sectors, but this has also been accompanied by a high level of job creation. Technological changes are gradually replacing part of the workforce and, at the same time, a qualitative reassessment of the workforce has begun.

\section{Material and methods}

In the Northern Hungarian region, the number of people employed in industry dominated until the change of regime, peaking in 1978 with 223,681 people employed. This fell sharply within a year to 185,772 in 1988 , and then fell to 93,282 in 1989. For agricultural employment, this fell from 92,438 to 85,845 in 1988 to 1989 , and in services the number fell from 105,452 to 102,694. The lowest point for industrial employment was observed in 1991 (73,634 persons in the region). Agriculture was not a solution for those who lost their jobs in industry either, as there was also a significant reduction in this sector. A similar low point in employment was reached in 1997 (in line with the national trend), when total employment stood at 229,983, followed by five years of stagnation and then a slight increase, explained by employment growth in the services sector and in light industry and assembly (Figure 1).

The Lilien index can be used to identify weights between regions in terms of the number of people employed in each sector. In his thesis, Lilien (1982) argued that in response to sectoral shocks, there is a reallocation of workers between sectors, and during the period frictional unemployment emerges at higher levels for longer or shorter periods, which ultimately keeps the natural level of unemployment high.

The Lilien index can be used to identify weights between regions by looking at the number of people employed in each sector. Lilien's thesis was that there is a reallocation of workers between sectors in response to sectoral shocks, and during the period frictional unemployment emerges at higher levels for longer or shorter periods, which ultimately keeps the natural level of unemployment high. The processes that occur due to structural shifts (sectoral shifts) and worker mobility have been termed labour market turbulence by Lilien (Lilien, 1982). 


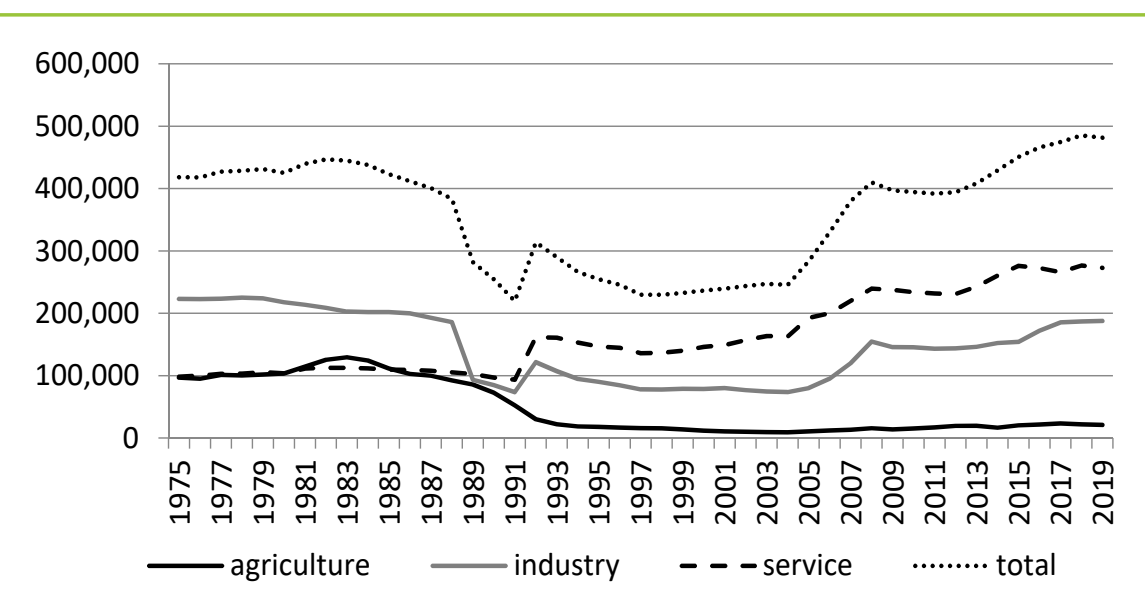

Figure 1 Number of persons employed by sector in the Northern Hungary (1975-2019) Source: own editing based on data from the Hungarian Central Statistical Office

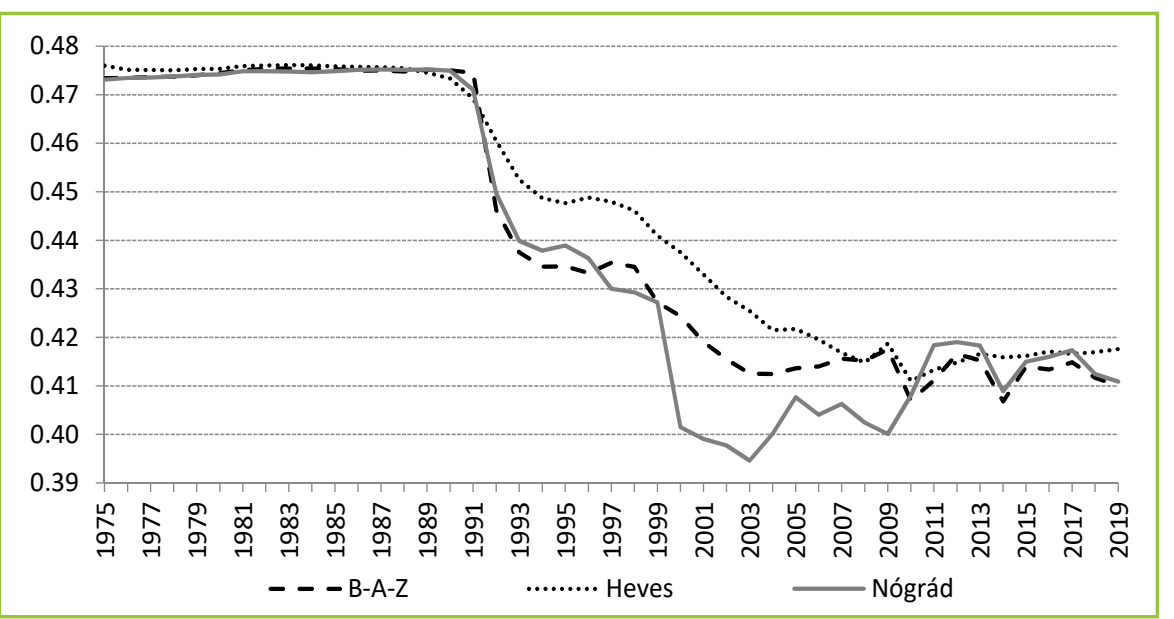

Figure 2 Changes in the Lilien index in the Northern Hungary (1975-2019) Source: own editing based on data from the National Employment Service

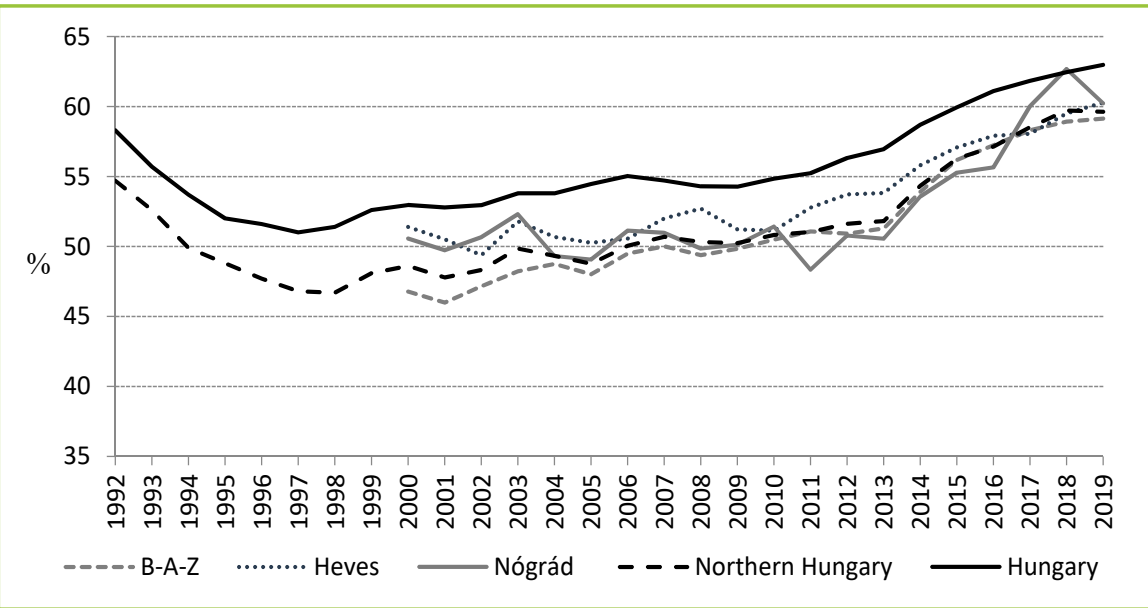

Figure 3 Activity rate (\%) in the Northern Hungarian region (1992-2019) Source: own editing based on data from the Hungarian Central Statistical Office

$$
L_{i}^{S}=\sqrt{\sum_{j=1}^{m} \frac{x_{i j}}{x_{i}}\left(\Delta \log x_{i j}-\Delta \log x_{i}\right)^{2}}
$$

where:

$\frac{x_{i j}}{x_{i}} \quad$ - the share of employment in sector $j$ in

$x_{i} \quad$ region $i$

$x_{i j} \quad$ - the number of persons employed in sector $j$ in region $i$

$x_{i} \quad$ - total number of persons employed in the $i$ region

$\Delta$ - first order differential operator (Lilien, 1982)

Based on the Lilien index (Figure 2), the sectoral rebalancing is clearly visible until the change of regime, after which the biggest rebalancing took place in the Nógrád county. The results of the post-crisis period are surprising, while the Heves and Borsod-Abaúj-Zemplén counties show a decrease in the index, the Nógrád county has experienced the opposite trend in the last two years. The sectoral shifts in the counties have started to "re-group" since 2009 , i.e. the indices have shown the end of the sectoral re-alignment, but this means a lower level of employment than was the case in the 1970s and 1980s. It can be concluded that sectoral labour flows have less and less influence on employment, and this is particularly true for the Heves County. In the case of sectoral employment, the eternal question is whether it is necessary to catch up a sector in a county. On the basis of the index, there does not seem to be any justification for a future regional employment policy to give priority to any one sector. The results of the Lilien index suggest that the Nógrád county could have been more in need of catching up from the 2000s onwards, but by 2010 this had become irrelevant. According to the Lilien index, sectoral labour flows in the Northern Hungarian region have had less and less influence on employment since the regime change, and a completion of the sectoral reallocation can be seen, but at a lower level of employment than before.

After the change of regime, employment rates have fallen significantly and open unemployment appeared in Hungary. Northern Hungary was characterised by lower employment and higher unemployment than the national average (Tóth, 2013). The former full employment and job security quickly disappeared and labour market was left in deep depression. In transition economies, moving from centrally controlled planned to free market economies, several processes typically took place after the regime changes:

1. economic liberalisation, 
2. market conditions became the primary regulatory factor.

Barriers to trade were removed, state-owned enterprises were privatised and the financial sector was given the opportunity to manage private capital. The impact of regime change has also been significant in the Northern Hungarian region.

The activity rate (Figure 3) was still high in 1992 after the change of regime, at 58.3\% nationally and $54.7 \%$ in the Northern Hungarian region. It was then falling significantly until 1998 , to $46.7 \%$ in the Northern Hungarian region $(51.4 \%)$, which was higher than the national rate (51.4\%). In the early 2000s, an improving trend emerges, broadly following the national trend. The evolution of the data series for the county of the Borsod-Abaúj-Zemplén is similar to that of the Northern Hungarian region, while the activity rates of the other two counties, in particular Nógrád, have been much more volatile. These changes are due to campaign-related changes in the number and proportion of people leaving active status. As a result of the economic crisis, the most significant decrease was in the Nógrád county, while the Heves county saw an increase. In the year of the economic crisis (2008), the activity rate was $49.4 \%$ in the Borsod-AbaújZemplén county, $52.7 \%$ in the Heves county and $49.9 \%$ in the Nógrád county, but it has increased in 2019 to $59.1 \%, 60.3 \%$ and $60.2 \%$, respectively.

In the case of a crisis, the labour supply was affected by two opposite effects. On the one hand, the persistently low demand for work has been accompanied by an increase in the share of unemployed people who have lost hope and have exited the labour market, leading to a decline in the activity rate. On the other hand, those previously in inactive status were able to re-enter the labour market. In Hungary, employment policy measures (abolition of early retirement pensions, revision of eligibility for disability pensions) have increased the activity rate (Cseres-Gergely et al., 2012). Hungary's working-age population has steadily declined over the past decade, from 6.4 million in 2006 to around 6.2 million in 2016. In the context of adverse demographic trends, maintaining the employment rate requires an increase in the activity rate, i.e. an increase in the number of people taking up or actively seeking work.

The employment rate (Figure 4) has varied in line with the activity rate, with a low point in 1996 when the employment rate in Hungary was $46.4 \%$. In the Northern Hungarian region it was $40.3 \%$, while in the Borsod-Abaúj-Zemplén county it was $44.5 \%$, in the Heves county $45.0 \%$,

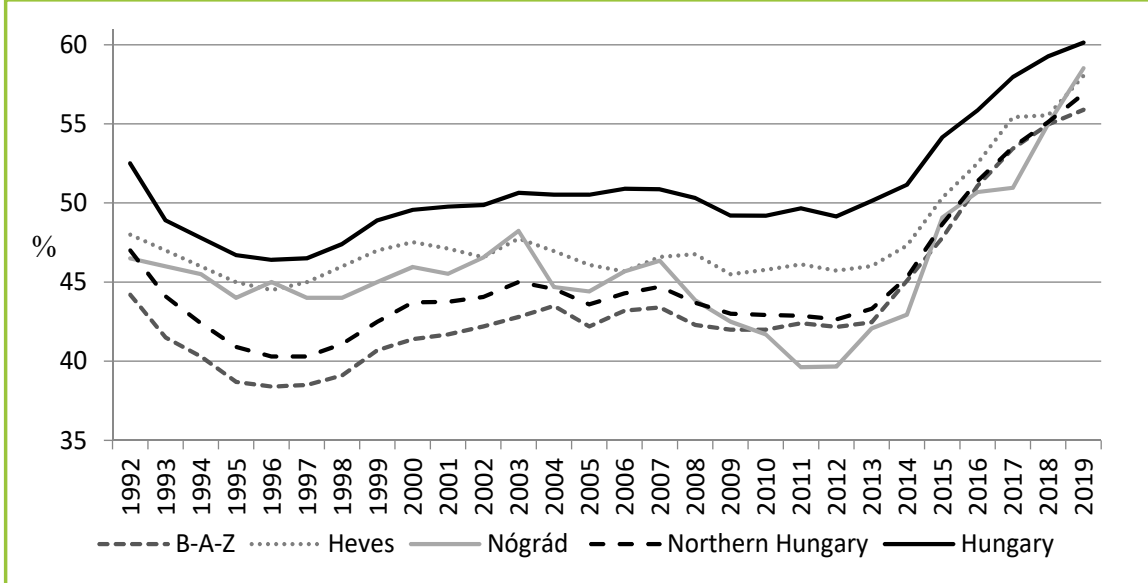

Figure 4 Employment rate (\%) in the Northern Hungarian region (1992-2019) Source: own editing based on data from the Hungarian Central Statistical Office and in the Nógrád county $40.3 \%$. Until the EU accession, there was a slight improvement thanks to complex employment policy measures. From 2005 onwards, the Nógrád county saw a sharp decline (43.6\%). In terms of employment rate, there is no phase difference between the national and the Northern Hungarian region. The low points of the employment rate curve are one year ahead of the minimum points of the activity rate. In other words, the depression in the labour market peaks one year later due to those in unemployment status. The employment rate in all counties and in the Northern Hungarian region is below the pre-crisis level, as the demand for labour increases little after the crisis. In 2008, the year of the economic crisis, employment was $50.3 \%$ nationally and $43.7 \%$ in the region, compared to $46.8 \%$ in the Borsod-Abaúj-Zemplén county, $43.9 \%$ in the Heves county, and $43.7 \%$ in the Nógrád county. Following the recovery from the crisis, the employment situation has improved and in 2019 the employment rate was $60.1 \%$ nationally, $56.9 \%$ in the Northern Hungarian region and $55.9 \%, 58.1 \%$ and $58.5 \%$ in the three counties, respectively.

The unemployment rate has changed more than the employment or activity rate. After a peak in 1993 (Hungary: 12.1\%, Northern Hungary: $16.1 \%)$, the rate reached its minimum in 2019 (Hungary: 3.4\%, Northern Hungary: 4.5\%), both nationally and regionally. Hungary's labour market is experiencing both a significant positive labour supply shock and a negative job demand shock. Labour supply has been boosted by the tightening of disability pension conditions in recent years, which has led to an increase in the activity rate. Since the regime change and the labour market crisis, the structural transformation of the economy has caused labour demand to shift and then fall, resulting in a steady increase in the unemployment rate (Figure 5) since 2000 (Cseres-Gergely et al., 2012). The lowest rate at both county and regional level was in 2001, after which a slow increase occurred, reaching by 2010

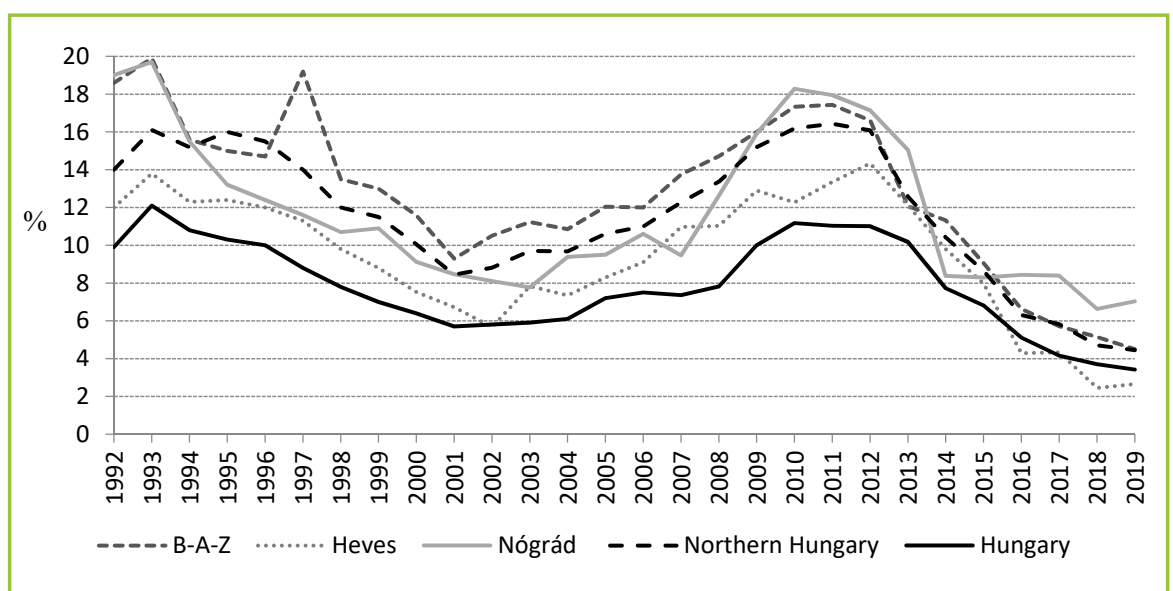

Figure 5 Unemployment rate (\%) in the Northern Hungarian region (1992-2019) Source: own editing based on data from the Hungarian Central Statistical office 

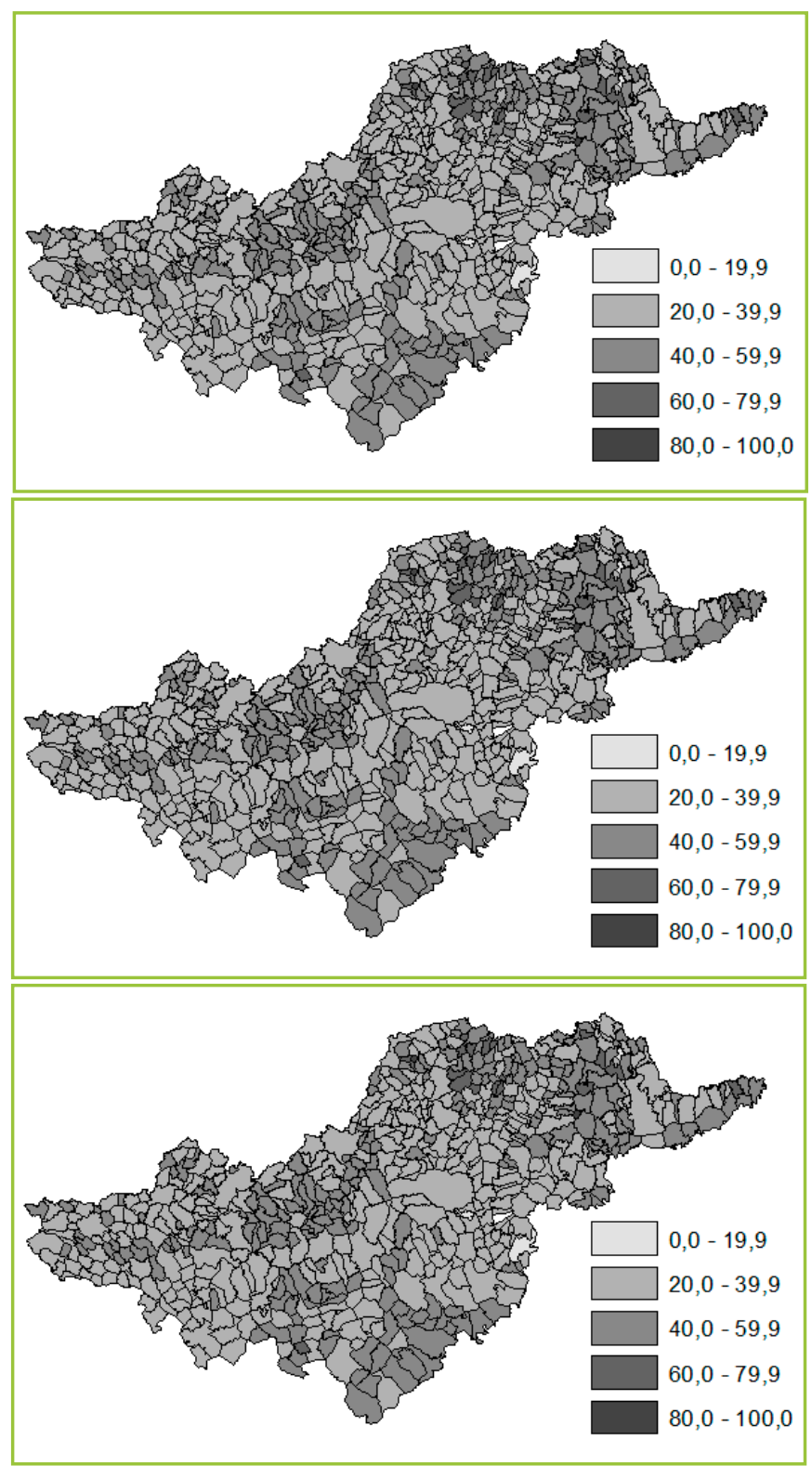

Figure 6 Share of households without employed persons (\%) 1990, 2001, 2011

Source: own editing based on census data

The Hungarian Statistical Office collects the proportion of households without employed persons only at the time of the census. Censuses are organised every 10 years in Hungary. The next census will be in 2022 (with a one-year delay due to the covid), so the dataset is no more recent than 2011. The last microcensus (2016) did not collect this data neither at micro-regional level nor settlement level the high unemployment rates immediately after the regime change (Hungary: 11.2\%, Northern Hungary: 16.2\%). The improvement of unemployment was accompanied by a regional convergence until 2001, after which the gap between the national and the Northern Hungary values has been widening again. The high level of unemployment rates is due to the region's lower than average business and industrial capacity. The unemployment problems are not the result of some short-term effects, but of specific characteristics between regions that have a long-term impact.

The proportion of households without employed persons per settlement varied across the three census periods in 1990, 2001 and 2011 (Figure 6). In the post-change census, the share of households in small villages around the Slovak border with no employed status was close to $60-80 \%$ (e.g. Tornakápolna 84\%, Gagyapáti 79\%). In larger municipalities, small and large towns, this figure was typically lower, around 20-30\% (Tiszaújváros 13\%, Mályi 20\%, Kazincbarcika 21\%, Miskolc 30\%). In this period, the impact of the regime change was not yet so noticeable, as it was still just the "golden age" of the labour market, with the regional average being $39 \%$.

By 2001, many more households were unemployed (the regional average was 56\%), in the small villages of Tornakápolna, Keresztéte, Teresztenye the proportion of households without an employed person was $95 \%$, but similarly high figures were also found in the inner (serehát (Gagyapáti 85\%, Gagybátor 89\%). Parádsasvár (22\%), Rétság (25\%) and Tiszaújváros (29\%) had the highest rates. By this time, the mass redundancies after the change of regime had already become noticeable, especially among older, retired people who could no longer commute to work from the peripheral villages. The loss of industrial jobs, the reduction in the number of railway lines and the lack of public transport and infrastructure further aggravate their situation. For those living on the periphery, there is really no alternative but to participate in public employment. The regional average has fallen to $50 \%$, but there are still municipalities where almost $100 \%$ of households are without a job (e.g. Szakácsi, Gadna, Litka). The situation was most favourable in the municipalities of Kerekharaszt, Rétság and Kistokaj, where a quarter of households were without employees.

$G$. Fekete (2006) presented the five main areas of the vicious circle of territorial underdevelopment (demographic imbalance, weak regional income generating capacity, under-utilisation of environmental resources, isolation and barriers to meeting needs) that are present in the case of the Northern Hungarian region and which together affect the low employment rate in the region. Simkó (2008) characterised the region after the regime change as a situation of sudden decline, economic collapse and severe crisis, where massive layoffs and continuous redundancies became a dominant labour market phenomenon. From the unfavourable geographical location, relatively underdeveloped infrastructure, to poor demographic outcomes, all these factors have further exacerbated the region's lagging behind the national average.

Since accession to the European Union, the region of Northern Hungary has become more marginalised compared to the rest of the country in terms of labour market and economic indicators. A previous research (Lipták, 2009) suggests that a reorganisation of the North-Hungarian region started before the economic crisis (from 2004). By 2008, the division of the country into two parts became even more evident, with increasing disparities between the parts and a levelling out within the parts. Further fragmentation of the Northern Hungarian region was observed when looking at complex indicators. Káposzta et al. (2010) examined in detail the socio-economic situation of the North-Hungarian region, including the Borsod-Abaúj-Zemplén county, at the level of sub-regions. Their results show that increasing unemployment is a key factor of social and economic disintegration. G. Fekete (2006) presented 
the five main areas of the vicious circle of territorial underdevelopment (demographic imbalance, weak regional income-generating capacity, inadequate use of environmental resources, isolation and obstacles to meeting needs) that are present in the Northern Hungarian region and which together affect the region's low employment rate._Simkó (2008) characterised the region after the regime change as a situation of sudden decline, economic collapse and severe crisis, where massive layoffs and continuous redundancies became a dominant labour market phenomenon.

Several researchers (Fazekas, 1997; G. Fekete, 2006; Siposné, 2016; Szendi, 2017; Hajdú, 2021) agree that the unfavourable labour market situation in the North-Hungarian region was the result of the complexity of the problems.

\section{Local labour market trends}

The labour market is also facing global challenges, such as the development of technology and the decline in the demand for living labour, outsourcing of activities, the expansion of services and the spread of infocommunications activities. At the same time, local responses such as labour migration, commuting or teleworking, the launch of local services not yet covered, the integration into infocommunication networks, community tasks and the intensification of socially useful activities are also intensifying.

With the global reallocation of the labour market, one can observe territorial imbalances in the labour market, together with a disruption of the balance between supply and demand. In addition to high unemployment, high labour shortages are also a problem in this two-faceted labour market, but high unemployment is still the main problem at the municipal level. Unemployment is a social fact, but state intervention can help. As the lack of work is at the root of so many problems, there are few public objectives as important as reducing the number of unemployed and increasing the number of people in legal employment. In line with the European Union's ambitions, it is also considered important at local level to combat social exclusion, improve the employability of disadvantaged groups and strata, strengthen local communities, reduce discrimination, increase tolerance, improve the quality and accessibility of social services, and develop professionals. Management alternatives include bringing the workforce to the workplace or bringing the workplace to the workforce and increasing the number of local jobs.

To reduce long-term unemployment, no effective help can be expected from the actors of the first economy, neither from the market sector nor from public bodies forced to downsize. It is therefore appropriate to rely on non-profit organisations and local initiatives to provide them with a more promising solution than the current one. One way to do this could be to support the employment initiatives of non-profit organisations, i.e. to create jobs outside the mainstream labour market.

\section{Results and discussion}

\section{The role of local development in peripheral areas}

The changing labour market challenges are amplified at the municipal level and require local solutions, which is where the importance of local development comes in. Elements of the concept of local development include the fact that local development builds on local resources, addresses local needs, involves local actors and is locally controlled.

The first example is Boldva, a village in the Borsod-Abaúj-Zemplén county, where cold-pressed pumpkin seed oil is produced and sold with the help of public employees. Nowadays, local products are increasingly in demand throughout the country, as the countertrend of globalisation is beginning to return, and we are trying to buy more consciously, looking for products and foodstuffs that are made in our country or perhaps in our region, or come from there. Buying these products not only reflects consumer awareness, but can also lead to a boost for the domestic economy. If we look at this in an even narrower perspective, local products are one of the ways in which many small regions and municipalities can tap into the economy. At the same time, local products also play a role in the development of the area, because in order to produce something, the raw material has to be produced, the product has to be manufactured and sold, and this also creates employment (Burka and G. Fekete, 2017).

Pumpkin seed oil is the primary product of the Boldva oil plant, which was set up to produce it. Public employment is a state-subsidised form of employment, the aim is to maximise employment and thus reduce unemployment. In Boldva, this is done through the Start Public Employment Programme, which includes farming, cultivation of medicinal herbs, oilseeds and other agricultural products. It also follows that the logic behind the plant here is to provide work for as many people as possible by growing and harvesting the oil, pressing the seeds and packaging the oil. The oil stalks are grown on their own land, using semi-mechanised methods, making a major contribution to the small-scale exploitation of local resources, and also eliminating and minimising transport costs in the 'raw material procurement' process. Waste generation is also lower due to the recovery and sale of by-products. A well-maintained factory environment is emerging, with a previously unused, derelict building being renovated for the plant. The plant, run by the Boldva municipality, has highlighted local entrepreneurs as prospective partners. Pumpkin seed oil pressing has been in operation for a few years, so it is still in its early stages. The result is employment as a positive economic impact, but not as significant due to the small number of employees. In the long term, the aim would be self-sustainability.

The public employment programme in Hernádszentandrás, in the Northern Hungarian region, has been organised along similar lines, producing and selling vegetables under the BioSzentandrás brand. As a result of several years of work, they have been practising organic farming, which further increases the market value of the raw materials produced. It currently provides employment for 25-30 people. The social innovation there lies not only in the production of vegetables, but also in the social process that is being carried out with the involvement of civil society actors. It is seen as a complex local development, as the land and labour were available to create the new farming model, but the knowledge, resources and connections were lacking. These were supported and generated by targeted actions linked to the personality and ideas of the "local hero", the mayor. It is also innovative in that it incorporates the idea of social responsibility, rejecting processes that seek to maximise profit. Learning is inherent to local economic development, a process that can be seen in the changing understanding of problem solving (Nemes and Varga, 2015). Social learning can therefore be defined as a capacity that enables a community to do something it would not have been able to do before.

\section{Conclusions}

In order to develop regional employment policy in the Northern Hungarian region, a multi-channel employment policy combining traditional forms of employment and local employment development solutions would be justified in the long term. To achieve this, it is not sufficient to decide at regional level, but rather to ensure macro-level socio-economic conditions, and a change of 
approach is essential. The changing meaning of the concept of work and the changing nature of work are increasingly bringing non-traditional forms of employment to the fore.

A sustainable labour market must address traditional employment and local employment development together. It would be appropriate to develop a regional employment policy with its own regional objectives, instruments and institutions. In the EU, the regional approach is present in many areas, and this approach is also increasingly justified in the case of employment and the labour market. Regional employment policy would require a separate set of instruments and a separate set of institutions, which would not always be the same as those applicable in other regions of the country.

It can be concluded that local employment solutions and local initiatives are important for the sustainability of the labour market in small villages and small towns, as they can effectively address labour market problems that are also being experienced at local level due to the effects of globalisation.

\section{References}

Burka, N. - G. Fekete, É. 2017. A hidegen sajtolt tökmagolaj, mint helyi termék szerepe a helyi fejlődési folyamatokban. In: Lipták, K. (eds): Társadalmi innováció és felelősségvállalás Észak-Magyarországon, Miskolc, 2017, pp. 43-54.

Cseres-Gergely, Zs. - Kátay, G. - Szörfi, B. 2012. A magyarországi munkapiac 2011-2012ben. In: Fazekas, K. (eds.) Munkaerőpiaci Tükör, 2012, pp. 18-40.

Fazekas, K. 1997. Válság és prosperitás a munkaerópiacon - A munkanélküliség regionális sajátosságai Magyarországon 1990-1996 között. In Tér és Társadalom, vol. 11, 1997, no. 4, pp. 9-24.

G. Fekete, É. 2006. Hátrányos helyzetből előnyök? Elmaradott kistérségek felzárkózásának lehetōségei az Észak-magyarországi régióban. In Észak-magyarországi Stratégiai Füzetek, vol. 3, 2006, no. 1, pp. 54-69.

Hajdú, D. 2021. Distribution of Adult Education Participants in Borsod-Abaúij-Zemplén County. In Visegrad Journal on Bioeconomy and Sustainable Development, vol. 10, 2021, no. 1, pp. 24-28.
Káposzta, J. - Nagy, H. - Kollár, K. 2010. Borsod-Abaúj-Zemplén és Szabolcs-Szatmár-Bereg megye leghátrányosabb helyzetű kistérségeinek településszerkezeti, foglalkoztatási jellemzői az EU - csatlakozás óta eltelt időszakban. In Területi Statisztika, vol. 50, 2010, no. 6, pp. 641-658.

LENGYEL, L. 1968. A foglalkoztatottság területi alakulása. In Statisztikai Szemle, vol. 46, 1968, no. 3, pp. 235-54.

Lilien, D. M. 1982. Sectoral shifts and cyclical unemployment. In Journal of Political Economy, vol. 90, 1982, no. 4, pp. 777-793.

Lipták, K. 2009. Kistérségi szintű HDI becslés az Észak-magyarországi régióban. In Doktoranduszok Fóruma Miskolc, 2009, pp. 1-7.

Nemes, G. -Varga, Á. 2015. Társadalmi innováció és társadalmi tanulás a vidékfejlesztésben. In Mérleg és Kihívások IX. Nemzetközi Konferencia, Miskolc, 2015, pp. 434-444.

Simkó, J. 2008. A foglalkoztatás aktuális problémáira megoldást javasoló módszerek az Észak-magyarországi régióban. Miskolc, 2008.

Siposné Nándori, E. 2016. A munkaerôpiaci hátrányok területi vonatkozásai ÉszakMagyarországon. In Területi Statisztika, vol. 56, 2016, no. 4, pp. 438-454. D0l: 10.15196/TS560405.

SZENDI, D. 2017. The Connection of EU Supports and the Taxable Income per capita in the Northern Hungarian region, for the 2007-2013 period. In DETUROPE, vol. 9, 2017, no. 3, pp. 42-60.

Tóth, I. J. 2003. Észak-Magyarország gazdasági helyzete, 1990-2001: Adatok, tendenciák, elemzések. Budapest, 2003.

\section{Contact address}

Katalin Lipták, University of Miskolc, Faculty of Economics, 3515 MiskolcEgyetemváros, Hungary, e-mail: liptak.katalin@uni-miskolc.hu 